\title{
My Experience with the Sengerema Community Multimedia Centre (CMC)
}

\author{
By Mr. Felician B. Ncheye \\ Chair Local Steering Committee, \\ Sengerema Multipurpose Community Telecentre
}

\section{Introduction}

The Sengerema Multipurpose Community Telecentre turned five years old by January 2006.

The objective, the vision and the Mission all paint a picture of the role of the Centre to its audience. In a nutshell the role of the center is to make the community of Sengerema get the knowledge what is demanded for them to realize their proper destinies.

\section{Launching of the Project}

No wonder the Project was initiated in agreement with the most wise King when he said, 'My people are destroyed because of lack of knowledge' also, supporting Glenn Bland's philosophy that "there is a way to a happy and successful life". It is true there is a line when one crosses this line enjoys happiness and successful life. This underscores the fact that knowledge is a fundamental aspect of development issues. The question is how one should know that there is this line and the way to cross it. To know the way begins with becoming success conscious which will make one develop a hunger for wisdom and truth and begin to search for everything that will satisfy that hunger. Paraphrasing Dr. David Oyedepo's statement, "Wisdom is all you need to have your needs met. He adds that; "searching wisdom in truth is what makes the journey of life swift and set".

Global development initiatives, particularly the World Summit on the Information Society (WSIS) and the UN Millennium Project recognize the impact of Information and Communication technologies as enabler for sustainable development and the achievement of the Millennium Development Goals (MDGs) which have much concern on sustainable human development and poverty reduction. The discourse on ICT is changing to emphasize the human and development dimension of information and Communication technologies. This implies that ICT facilities like the Sengerema Multipurpose Community Telecentre are one of the most effective machineries to access the much-needed wisdom to our communities.

Appropriate method and techniques should be put in place that will contribute in conceptualization and implementation of programmes and projects that through expertise, Experience and skills will provide the knowledge through which our communities will be able to realize the ability to access facilities that shall give wisdom needed to satisfy their hunger.

Our societies, especially, most of the Sengerema population have to be imparted with the knowledge which will lead them to access wisdom of the ages like 'the principles about success has been provided by the creator and are free for the taking'. It is of paramount importance to enlighten our communities that as we search more for the information to satisfy our hunger that is the way we grow. As we grow our understanding grows and more of the wisdom of the ages is gained. We are limited in understanding only by our willingness to abide to principles and to grow.

I hope one will agree with me that most of the people in this part of the World are not aware of some of the basic principles like; "Men with goals and plans dictate to others, while those who have no goals or plans are dictated to" People should not be drifting, they must have real direction, goals and plans. One should bear in mind that best results are achieved only when you do something you wanted to do and not because you had to do it. Do they have the idea that" Most of the resources that make the world rich are found in Africa"? This kind of wisdom have to be accessed to them, in return they will develop an attitude which will give them the confidence and hope that it is possible for them to change their situations for the better by properly utilizing the resources around, provided they abide to principles.

I believe at this level we shall have laid a foundation to support strategies put in place following the agreement finalized by heads of states at WSIS - Tunis phase 2005 on how to finance infrastructure that will better integrate the poor into the information society and shed light on who should govern the resources and technology infrastructure underpinning the information society.

I am convinced that this is the main challenge for the Sengerema Multipurpose Community Telecentre. It is 
imperative that we hold it responsible to transform the Sengerema Community in the name of the women, men, youth, voters, marginalized, etc, and create opportunities for all citizens to voice their own concern and priorities without mediation by some other person or structure. What I mean is that it has the opportunity to play a key role in imparting the wisdom in question.

For the last five years implementation of various activities was carried out on the basis of the objective, Vision and Mission laid down during conceptualization of the project. Amongst were; Computer training programmes, with the view of giving the community the knowledge that will enable them to utilize the ICTs to access crucial information such as surfing the Internet to look for agricultural, fisheries, business, educational for development. Secondly, the Internet café's service with the aim of giving the community the opportunity of accessing important domestic and international data for sustainable development recognizing that basic access to internet would provide a sound basis for achieving a people-centered and development oriented information society. Also Community Radio programmes mainly for dissemination of information important for enlightening communities about what is happening around and enable them to share knowledge and entertainment. The Centre also carried out secretarial services, conferences, hall facilities and video camera shooting as complimentary activities.

\section{Implementation}

In 2001, when the project-started, computer was a rare item in the district. Only two individuals had computers, while none of the public offices had any. This means emergence of computers in the Sengerema community would be a new phenomenon. Our project started with 9 Dell 486 refurbished computer offered by UNESCO, I Compaq machine (Pentium III), I LaserJet $1100 \mathrm{Hp}$ Printer and a telephone receiver. The modules we started with were four namely; introduction to Windows, MS Word, MS, Excel, MS Access and MS Power Point. We started with 56 students in the first month and at the end of the year 556 persons in the community had been accessed to this important phenomenon. At the end of fifth year (2005) above 2000 (45\% male and 55\% female) had been accessed, Profound achievement is that in addition to youth from districts of the Lake Zone regions who constitute the biggest number in computer training, staff from all departments of the Sengerema district Local Council have undertaken studies here at our Centre.

Due to some infrastructure problems, Internet surfing started a year later where about 12,000 people (14.5\% female and $85.5 \%$ male) have accessed the Internet. However, it is encouraging to find that the community has appreciated these services and they are making use of them by making contacts with either their suppliers or customers outside Sengerema district. More interesting is awareness by the 18 economic activity groups under the umbrella of the Sengerema Informal Sector Organization that use the Internet at the center to look for partnerships and markets for their activities and commodities respectively. Some of them have succeeded to obtain customers from the neighboring regions after marketing their products using the Internet at the Centre.

The Community Radio contributed by UNESCO became operational by July 2003. It has become a strong force for information dissemination and participation in the community. It has been so popular simply because it serves our community with content that reflects specific needs and characteristics of our society and passes on information about up-to date events relevant to the community's life patterns and settings

The Community Radio, being supervised by a womens group namely, "Wanawake wa Habari na Maendeleo Sengerema (WAHAMASE)" has the mandate to reach the community with positive information and provide information about methods and techniques that empower both men and women at affordable costs.

The Community has enjoyed an easily accessible radio where they can, at their convenience, send urgent and important messages like death announcements, wedding and other celebrations arrangements etc. You would be surprised to note that $54 \%$ of the announcements are used by the community to exchange greetings, while $35 \%$ are issued by the business community. The remaining $11 \%$ is used for searching for lost children and relatives.

The Sengerema Local Government is using the radio to enlighten the community in various regulations and civic practices and related social issues like, voting, human rights, and proceedings of District Local Council meetings.

The Local government is using the Centre to train their staff and extract important data from the Internet café. The number of students undertaking distance learning is increasing because of easy accessible data on the Internet

\section{Challenges}

Challenges facing the projects include; unreliable Internet network because of poor infrastructure, interruptions in the radio programmes due to power cuts and uneven radio coverage due to the height of the radio antennae being not sufficient.

In a quick analysis you find that the center has fulfilled its role of making the community aware of the availability of ICT facilities and to some extent their potentials for development. I ague that even if they utilize the ICTs and inputs available, without employing the human ingredient which is necessary for giving fruits we shall see not expected results. 


\section{Way Forward}

From this experience I would like to share with you the following;

Now the Centre is growing. Growth likened to the human body, which develops muscles to match its level of growth, it has to grow to match particular weights of function. Similarly, for Sengerema Multipurpose Community Telecentre and the like to cope with the information revolution as envisaged by the WSIS and MDGs, and most importantly the great need to impart wisdom in communities in a most effective way. There must be a building up of objectives, visions and mission in our Centres to reflect relevant function. The agreement finalized by heads of state at WSIS - Tunis phase 2005 will be fruitful only if we aim at greater growth.

We should see that these centers are geared to impart wisdom that will give the community faith in their potential. They must be organized and managed in the manner that ensures that the output abides to these principles. Practitioners have to put it clear that it is only when you abide to principles that you're assured of success. They must be made aware of the irrelevant principles. They must have the attitude that these centers are the sources of transformation of our societies. I was very impressed by the comment of the Project Coordinator of the Sengerema Multipurpose Community Telecentre when he advised me to see Sengerema MCT as an excellence center for the Sengerema community. This is the kind of attitude to be cultivated to all stakeholders.

Management system has to be in line with this am; there must be an ownership sense for supervision and monitoring if we need to be effective. We should not take it for granted and just recruit employees through paper qualifications, entrusting all functions to them while shareholders relax. Shareholders should devise structures that ensure involvement in development, close supervision and monitoring for both the Centre's sustainable development and for achieving its aims.

This kind of center should play the role of organizing forums that will provide platforms for members and partners to share experiences, develop collaborative programmes and keep abreast of important trends and innovations at the grass roots level.

I wish to underscore the need for the focus of the Centre's activities to impart wisdom to our communities, this is simply because, "Wisdom" has all what it takes to meet all you need in life e.g. to reduce poverty, corruption, drug abuse, violence and eliminate HIV/AIDS. Hence, achieve sustainable development. I believe most of the population is not aware of the potential of wisdom as you find here below;

I, Wisdom, give good advice and common sense. Because of my strength, kings reign in power. I show the judges who is right and who is wrong. Rulers rule well with my help. I love all who love me. Those who search for me shall surely find me. Unending riches, honor, justice and righteousness are mine to distribute. My gifts are better than the purest gold or sterling silver. My paths are those justice and right. Those who love me and follow me are indeed wealth.

In this context, Wisdom does not mean words said by intellectuals but the power behind success. The Centre will have the challenge of identifying what is this power and how to obtain it. Devising techniques and methods that will be used in the process without compromising our laws and regulations.

One thing I am sure is that, if we succeed to impart this Wisdom the global policy debates and action towards improved communications for sustainable development will have achieved fruition. From practical experiences, I believe in its potency. 